\title{
International Administration
}

Law and Management Practices in International Organisations

edited by Chris de Cooker

1990, $416 \mathrm{pp}$.

ISBN 0-7923-0465-9

BW $\$ 119.00 /$ Dfl. $235.00 / £ 86.00$

Martinus Nijhoff Publishers, Dordrecht/UNITAR

Also available from the UN. UN sales no. E9O.III.K.ST/29

International Administration: Law and Management Practices in International Organisations describes the law and practice of the internal functioning of international organizations. It deals with questions such as recruitment and retention policies of the staff of international organizations, the differing environments in which these employees work, their privileges and immunities, staff representation, and the judicial remedies open to staff. It also deals with such topics as social security and pensions, the relationship between the Heads of the organizations and Member States in staff and administrative matters, the administrative coordination between organizations, and the need for reform in times of (financial) crisis. The contributors all have a wide experience in international administration.

This publication is of interest not only to students of administrative sciences, but to staff representatives, personnel departments and legal departments of international organizations as well as of Ministries of Foreign Affairs and trade missions.

International Administration will be supplemented annually with approximately 100 pages of new contributions.

For the reader's convenience we have included the first supplement (1990) in the basic work.

\section{Contributors}

Judge $M$. Lachs, A. Ali, J. Tassin, D.J. Goossen, $M$. Bertrand, R. Oosterlinck, $Y$. Beigbeder, C. de Cooker, H. Schebesta, A. Plantey, S. Tarassenko, R. Zacklin, F. Morgenstern, W. Fürst, H. Weber, F. Gutteridge, C.F. Amerasinghe, T.O. Elias, C. Bourtembourg, B. KjolstadtErlandsson. 